DOI 10.37882/2500-3682.2021.12.09

\title{
СОВЕРШЕНСТВОВАНИЕ КОММУНИКАТИВНЫХ НАВЫКОВ У ПОДРОСТКОВ С МЕНТАЛЬНЫМИ НАРУШЕНИЯМИ
}

\section{IMPROVING COMMUNICATION SKILLS IN ADOLESCENTS WITH MENTAL DISABILITIES}

K. Ignatov

Summary: The article reveals the peculiarities of adolescence and mental disorders in this category of people. It presents ways to improve communication skills, provides examples of their improvement as a factor of successful socialization and adaptation in society. The features of working with this category of persons are highlighted. Actions when working with this category of persons should be based on a comprehensive and systematic work, taking into account all the features inherent in these adolescents.

Keywords: student, teenager, communication skills, communication skills, mental disorders, intellectual disorders, special psychology, social psychology. одростковый возраст является уникальным периодом формирования личности. Это важнейший жизненный этап развития и закрепления социальных и эмоциональных привычек, имеющих немаловажное значение в первую очередь для психического благополучия.

Формирование многих навыков, одним из которых является коммуникация, - залог успешной социализации. Система межличностного общения играет особую роль на определенных жизненных этапах. Характер взаимоотношений особенно важен в подростковом возрасте, так как для данной категории общение - это один из основных видов деятельности. Чтобы достичь взаимопонимания с собеседником необходимо обладать способностями, навыками и умениями коммуникации, быть компетентным в этом направлении. На основе этого формируется соответствующее межличностное общение по типу подросток/подросток, подросток/взрослый, подросток/младший школьник и т.д. Компетентность и грамотность в общении - один из немаловажных факторов в любой сфере жизнедеятельности.

В настоящее время существуют десятки определений понятия «общение». Каждое из них в определенной степени отличается друг от друга, в зависимости от научной области. Однако все они отражают определённые грани взаимодействия людей. [1, С.2]
Игнатов Константин Александрович

ГБПОУ г. Москвы «Московский индустриальный колледж» etrionwwq@gmail.com

Аннотация: В статье раскрываются особенности подросткового возраста и ментальных нарушений у данной категории людей. В ней представлены способы совершенствования коммуникативных навыков, приведены примеры их совершенствования, как фактора успешной социализации и адаптации в обществе. Освещены особенности работы с данной категорией лиц. Действия при работе с данной категории лиц должны базироваться на комплексной и системной работе сучётом всех особенностей присущей данным подросткам.

Ключевые слова: ученик, подросток, коммуникативные навыки, навыки общения, ментальные нарушения, интеллектуальные нарушения, специальная психология, социальная психология.

Исследованием данного вида деятельности занимались такие педагоги и психологи как А.В. Петровский, М.И. Лисина, П.Я. Гальпер, А.А. Леонтьев, Л.С. Выготский и др. В основе их работ заложена мысль о том, что общение - это сложный процесс, взаимодействия двух и более людей, с целью установления и развития контактов, обмена информацией, навыками, знаниями. Прослеживается идея единства общения и деятельности.

Л.С. Выготский определяет, что основной функцией общения является коммуникативная. В психологии это связывается с содержательной стороной общения. Вместе с тем в педагогике понятие «коммуникативные навыки» объединяет широкий комплекс умений, владение которыми обеспечивает полноценное включение человека в процесс общения. [2, С. 10] Таким образом, коммуникативные навыки - это выработка навыков общения, формирование умения выражать свое мнение, аргументировать и отстаивать его, а также умение слушать.

На сегодняшний день отмечается низкий уровень коммуникативных навыков у детей, в том числе и у подростков. Факторов, влияющих на данную ситуацию множество. В России увеличивается процент детей, относящихся к группе риска. Самая многочисленна из них - это дети с ментальными нарушениями.

Большинство ученых определяют термин ментальные нарушения как тяжелые нарушения психического 
развития, при которых, прежде всего, страдает способность к социальному взаимодействию и поведению [3, C.4]. В данном случае у детей проявляется психические и/или интеллектуальные расстройства. По данным ВОЗ, половина всех нарушений возникает до наступления 14-летнего возраста.

В настоящей статье мы обращаем внимание на подростков с нарушениями интеллектуального развития, а именно - речи. В настоящее время дети с ментальными нарушениями обучаются в специальных школах или индивидуально. В применении к образовательным организациям трудности связанные с коммуникативными и речевыми навыками являются значимой и распространённой проблемой для обучающихся данной категории. В системе обучения и воспитания детей немаловажная роль принадлежит именно общению, так как они развиваются именно через этот вид деятельности. В следствии чего главной задачей в работе с данным контингентом является формирование и развитие коммуникативных навыков, которые, в свою очередь, способны оказывать позитивный эффект в улучшении познавательной, эмоциональной, двигательной сферы ребенка. Среди основных проблем, которые часто возникают у подростков, можно выделить трудности в понимании речи, отсутствие или недостаток развития коммуникативных навыков и умений, а также трудности в совместном взаимодействии со сверстниками и взрослыми. [1, С. 2]

В последнее время проблеме различных ментальных нарушений у детей уделяется больше внимания. Формирование, развитие и совершенствование навыков и средств коммуникации у детей с интеллектуальными нарушениями является одним из специфических и трудных разделов работы. Речь у обучающихся с ментальными нарушениями была предметом целенаправленного изучения как отечественный специалистов, так и зарубежных коллег, которые освещали эту сложную проблему с различных сторон. Э. Сеген, А. Бине, Т. Симон и др. расценивали недостатки речи как ведущий критерий аномалии интеллектуального развития и десоциализации.

Подростковый возраст коренным образом отличается от всех других периодов. При интеллектуальных нарушениях все сложности данного жизненного этапа усугубляются. Поэтому процесс развития и совершенствования навыков у таких подростков имеет свои особенности.

Дети с интеллектуальными нарушениями представляют собой неоднородную группу. Обучающиеся отличаются друг от друга по уровню речевого развития. Большинство из них не в полной мере понимают вопросы и обращенные к ним реплики, сами говорят немного и неразборчиво. Однако некоторые обучающиеся относительно свободно пользуются средствами общения, в первую очередь вербальными. Отмечаемые особенности обусловлены определенными причинами. К их числу относятся физиологические, психические, а также социальные. Чем серьезнее выражены интеллектуальные нарушения, тем, как правило, медленнее и, возможно, с затруднениями будет происходить совершенствование коммуникативных навыков. Однако некоторых успехов этот ребенок способен достичь благодаря своей способности к подражанию, обнаруживающейся, в частности, в плане имитации речевых звуков, их сочетаний, слов. Существенно отличаются друг от друга в речевых проявлениях дети, относящиеся к числу заторможенных, и возбудимые олигофрены. Первые - это молчаливые, крайне немногословны дети, говорят тихим голосом, в замедленном темпе. У вторых - речь быстрая, часто неуместно громкая. Им легко даётся общение с людьми, но во время диалога им сложно не упустить из вида суть разговора, поэтому, в какой-то момент времени, они могут перестать слушать собеседника. Это проявляется в озвучивании неуместных, неожиданных, а подчас и нелепых высказываний, которые нередко представляют собой механически усвоенные речевые штампы. [4, С. 16]

Владение не в полной мере коммуникативными навыками и средствами общения значительно затрудняет внутреннее раскрытие ученика и его реализацию в учебе, в кругу общения среди сверстников и за его пределами - обществе, всё это способно привести к выработке неконструктивных способов взаимодействия у подростка и, как итог, возникновению отклонений в его социализации. Стоит отметить, что возможность коррекции и совершенствования уже усвоенных и закреплённых коммуникативных навыков существует. Следовательно, нужно уделить внимание социально-педагогической работе, поскольку такой вид деятельности является достаточным для достижения результантов в силу особенностей данного возраста. [5, С. 20]

Согласно концепции О.С. Никольской, Е.Р. Баенской, М.М. Либлинг формирование, а также совершенствование навыков коммуникации необходимо реализовывать с помощью организации соответствующих внешних поддерживающих условий поведения, через специально созданное материальное и социальное окружение.

В последнее время проблеме интеллектуальных нарушений у детей уделяется больше внимания. Специалисты образовательных организаций разрабатывают и реализуют программы коррекции с соответствующим планом работы. Она может содержать такие направления, как формирование, развитие и совершенствование умений выражать просьбы, требования, эмоции, чувства; называть, комментировать и описывать предметы, людей, действия, события, способствовать развитию диалоговых навыков и др. 
На сегодняшний день, чтобы преодолеть трудности, для детей с ограниченными возможностями здоровья существует комплекс упражнений обучения коммуникативным навыкам, а также их совершенствования. Наиболее распространенными и эффективными являются беседа, игра, сказкотерапия, прогулки, экскурсии, тренинги. Их можно организовывать индивидуально, в парах, в группах, можно использовать прием, когда одна часть детей выполняет, а другая наблюдает, анализирует. Это, безусловно, зависит от каждого конкретного случая или ситуации. [6, С. 30] В упражнениях следует делать акцент на взаимодействии учеников между собой, основной их задачей должно быть коммуникация, а именно донесение информации до партнера таким образом, чтобы он смог точно понять, что ему необходимо сделать.

Во время выполнения задания ученики активно используют такие материалы как словесный, наглядный и практический. Во время длительной работы у детей с ментальной недостаточностью неизбежен процесс снижения интереса и внимания к выполняемому заданию. В качестве стимулирования интереса и поддержания внимания может выступать смена формы выполняемого задания, определённые поощрения в виде призов или других форм, нацеленных на создание атмосферы успеха. Такое положительное воздействие можно достичь за счёт использования иллюстративного материала с изображением ситуаций из жизни, опорных карточек с образцами начала фраз, пиктограммы, подбор песен, пословиц.

Позитивное влияние на развитие и совершенствование навыков общения со советниками и взрослыми оказывают именно экскурсии на природу и в общественные места, а именно в аптеку, магазин, на почту или любые другие. Получение опыта во время общения в реальных условиях оказывает более плодотворный эффект, нежели в искусственно созданных, поскольку искусственно созданные условия отличаются большей безопасностью. Безусловно, чрезмерная тревога так же мешает отработке и закреплению навыков, и именно поэтому посещение общественных мест происходит под руководством педагога, в данном случае он выступает в роли поддержки и уже само присутствие знакомого лица способно оказывать успокаивающий эффект.

Совместное посещение общественных мест (почты, магазина, больницы, кинотеатра, музея и т.д.) служит для совершенствования умения вести диалог с работниками данных заведений и другими посетителями. Перед посещением таких мест следует провести подготовку - уделить время разбору и проигрыванию похожих ситуаций в учебной среде. Это знание поможет ребёнку сориентироваться во время диалога и испытывать меньше стресса. Так же сами прогулки и экскурсии приучают детей к взаимовыручке, проявлению внимания друг к другу, формирования ответственности и организованности.

Чтобы подростки с интеллектуальными нарушениями не испытывали трудности при взаимодействии со сверстниками и взрослыми, требуется серия занятий. Однако важное значение играет структура и глубина дефекта.

Очень важно, чтобы работа с такими подростками организовывалась грамотно, сохранялась системность действий. Проблема коммуникативных навыков у детей с интеллектуальными нарушениями, в подавляющем большинстве случаев, является комплексной, оказывать помощь необходимо медицинским специалистам, психологам, педагогам, и обязательно родителям. То есть преодолевать коммуникативные трудности, необходимо сообща. Это порой сложная задача, однако это будет способствовать совершенствованию коммуникативных навыков. Необходимо систематически направлять усилия на выявление и разработку оптимальных средств, рациональных методов и соответствующих приемов руководства, способствующих позитивному решению проблемы. [6, С.15]

Немаловажное значение имеет квалификация и уровень профессионализма со стороны специалистов. В настоящее время зарабатываются и реализуются соответствующие программы для подготовки кадров, организуется система повышения квалификации, профессиональной переподготовки. Однако повлияет не только уровень образования, но и личностные особенности специалиста. Доброе, терпеливое отношение, похвала окажет положительное воздействие на совершенствование коммуникативных навыков у подростка. [7, С.2]

Еще одной особенностью работы по совершенствованию навыков является формирование у подростков взаимоотношений с нормально развивающимися сверстниками. Данное направление будет эффективным, так как это позволит расширить социальный опыт, способствует появлению чувства товарищества, взаимопомощи, доброжелательности и, как следствие, окажется фундаментом для успешной социальной адаптации. Для другой же категории подростков общение будет способствовать формированию доброго отношения, желания оказать помощь.

Иными словами, необходимо создание положительного отношения к контактам со взрослыми и сверстниками. Следует выстраивать доверительную атмосферу, активно применять приемы обратной связи, что поможет пережить новый опыт взаимоотношений. Не профессионально организованные занятия, ставящие перед ребенком непосильные задачи, создающие перегруз, сочетающиеся со строгостью и наказаниями, подчеркива- 
нием неудач приводят к тому, что ребенок оказывается робким, замкнутым, будет более неуверенным в своих силах. [5, С. 13]

Развитие и совершенствование коммуникативных умений у подростков с интеллектуальными нарушениями подчеркивает значимость мотивации появления потребности в общении, учет личных интересов, что необходимо для возникновения и поддержания диалога. Для формирования этой потребности на передний план выходит необходимость создания положительного эмоционального фона, это должно проявляется в проявлении ребенком заинтересованности в теме беседы, интереса и стремления к понимаю точки зрения своего собеседника, желания донести своё видение ситуации. Поскольку вступление в прямой диалог является затруднительным для детей с нарушением интеллекта, трудно переоценить важность благоприятной атмосферы, способствующей раскрытию ребёнка с умственной отсталостью.

Большое значение имеют те жизненные условия, в которых находится подросток. Ребенок учится лишь у тех, кого любит, не боится, кому доверяет. А это значит, что именно родители будут его самыми лучшими учи- телями. С ребенком следует чувствовать себя спокойно и уверенно, стремиться чаще разговаривать с ним. Гаджеты не заменят общение с родителями. Ребенка не следует ограничивать в общении со сверстниками, а также необходимо работать в тандеме со специалистами. Любовь, терпение, забота - незаменимые составляющие. Участие в процессе со стороны родственников, значимых и близких людей, доброжелательное отношение, принятие своего ребёнка со всему достоинствами и недостатками - это всё способно создать позитивный эффект и предпосылки к общему и речевому развитию, развитию интереса к окружающему миру, стремление к взаимодействию с другими людьми. [5, С.18]

Современность сложно представить без общения. Оно играет немаловажную роль в жизни человека. В подростковом возрасте этот процесс приобретает особое значение, так как этот вид деятельности выступает главным условием личностного роста. Совершенствование коммуникативных навыков у подростков с ментальными нарушениями обусловлена идеей воспитания человека коммуникабельным, владеющим культурой общения и межличностного взаимодействия. Для этого требуется комплексная и системная работа, которая, в свою очередь, способствует положительной динамике.

\section{ЛИТЕРАТУРА}

1. Рязанова И.Л. Оценка коммуникативных навыков и подбор альтернативных и дополнительных средств общения детям с ТМНР // [Электронный ресурс] // https://cyberleninka.ru (дата обращения 09.10. 2021)

2. Лукина И.В. Формирование коммуникативных навыков у обучающихся с умственной отсталостью (интеллектуальными нарушениями) на уроках социально-бытовой ориентировки [Электронный ресурс] // URL: http://elar.uspu.ru/bitstream/uspu/6531/1/12Lukina.pdf/ (дата 0бращения: 08.10.2021)

3. Иванова С.П. Ментальные нарушения у детей // Вестник образования, 2017, №5, С. $28-34$

4. Старкова, Н.В. Формирование коммуникативных навыков у обучающихся с умеренной и тяжелой умственной отсталостью [Текст] / Н.В. Старкова // Социализация детей с интеллектуальными нарушениями в контексте модернизации системы образования: опыт, проблемы, перспективы: сб. материалов Всеросс. науч.- практ. конф. 26 марта 2015 г. / под общ. ред. С.В. Соловьевой; ГАОУ дПо СО «Институт развития образования», Кафедра методологии и методики образования детей с ограниченными возможностями здоровья и детей, оставшихся без попечения родителей. - Екатеринбург: ГАОУ дПо СО «ИР0», 2015. - С. 170-1734

5. Михайленко Т.А. Развитие коммуникативных навыков во внеурочной деятельности у обучающихся с умственной отсталостью (интеллектуальными нарушениями) в подростковый период [Электронный ресурс] // URL: http:// http://elar.uspu.ru/bitstream/uspu/6563/1/Mihaylenko.pdf (дата 0бращения: 11.10.2021)

6. Назарова, Н.М. Специальная психология [Текст]: учеб. пособие для студ. высш. пед. учеб. заведений // Н.М. Назарова. - М.: «Академия», 2000. - 517 с

7. Podgorecki, J. Communication Theories Review.W: Aktualne problem psychologii. T.I. szesc 19, Wydawnictwo Instytut Psychologii Akademii Nauk Ukrainy Kijow, 2007. - Ss.161-168.

8. Петрова 0.М. Особенности развития коммуникативных умений у подростков с нарушением интеллекта [Электронный pecypc] // https://cyberleninka.ru (дата обращения 09.10. 2021)

9. Примерная адаптированная основная общеобразовательная программа образования обучающихся с умственной отсталостью (интеллектуальными нарушениями) [Электронный ресурс] // URL: http://fgos-ovz.herzen.spb.ru/wpcontent/uploads/2015.pdf (дата обращения: 11.10.2017).

(с) Игнатов Константин Александрович (etrionwwq@gmail.com)

Журнал «Современная наука: актуальные проблемы теории и практики» 